\title{
Politics of Mobility and Stability in Authorizing European Heritage: Estonia’s Great Guild Hall
}

\author{
Sigrid Kaasik-Krogerus
}

"Europe starts here". At first sight the sentence seems simple and clear, signaling the starting point of Europe. Looking closer, however, the three words that form this claim enable us to make a variety of interpretations. To start with the last word, "here", gives the sentence a strong spatial dimension, implicitly drawing boundaries between "here", where Europe starts, and "there", when it ends. This boundary drawing also implicates a European space of which "here" is a part. Locating Europe "here" paradoxically both concretizes this sentence and Europe and increases confusion about the "here", since meanings of Europe are continuously (re)-negotiated in political and cultural processes in which "Europe" is entangled with a variety of other partly overlapping geographical scales like the local and national ones. Furthermore, as used in this sentence, "starts" can, besides geographically, also be interpreted

S. Kaasik-Krogerus $(\bowtie)$

Department of Music, Art and Culture Studies,

University of Jyväskylä, Jyväskylä, Finland

e-mail: sigrid.kaasik@helsinki.fi

(C) The Author(s) 2019

T. Lähdesmäki et al. (eds.),

Dissonant Heritages and Memories in Contemporary Europe,

Palgrave Studies in Cultural Heritage and Conflict, https://doi.org/10.1007/978-3-030-11464-0_6 
from a temporal perspective, denoting the very first moments of Europe. In sum, while aiming to fix the spatial and temporal starting point of Europe, the sentence concurrently indicates mobility in time and space.

"Europe starts here" is the slogan of the newest heritage initiative of the European Union, the European Heritage Label (EHL). This flagship initiative was launched in 2011, and twenty five member states have now confirmed their participation. ${ }^{1}$ Apart from in the EU policy documents, the slogan is used on the EHL webpages and at the awarded sites. According to the European Commission (EC) webpage, the objective of the EHL is to use cultural heritage to bring to life a European narrative of identity and belonging - a task that is at least problematic due to the EU's internal controversies and diversity (see the more detailed description of the EHL by Mäkinen and Turunen in this volume). By 2018, 38 sites with "European significance"-as they are framed in EHL terminology-have been awarded with the label. The sites form a system of meanings of what is "European" heritage, and the process simultaneously shows how the EU believes it has a special claim over the term "Europe". Therefore, the EHL can be scrutinized as a discourse, that is, as simultaneously a system of meanings and a social practice of meaning-giving (cf. Fairclough 1995, 2; Raik 2003, 27-28; cf. KaasikKrogerus 2016, 16).

Critical heritage studies distinguishes between the dominant, authorized heritage discourse (AHD) and other, competing discourses, like the ones representing the heritage of various communities (Smith 2006; see also Waterton and Smith 2009). Laurajane Smith (2006) writes that, as a social construct, AHD is closely associated with nationalism and national narratives, heritage-related expert knowledge, and an endeavour to "conserve and preserve" heritage for future generations. Taken for granted on national scale, this discourse is experienced as "normal" part of social reality, leaving its dominant position hidden (Waterton and Smith 2009). As Laurajane Smith (2006) and Vsenja Kisić (2017) point out, all heritage, including AHD, is inherently processual and dissonant. AHD's intrinsic attempts to conform to what appears to be normal, however, make it imperceptible and homogeneous (Waterton and Smith 2006, 13). As Tuuli Lähdesmäki writes in this volume, since AHD promotes common views and consensus, its idea and concept of heritage are not problematized. AHD has thus been criticized for lowering

\footnotetext{
${ }^{1}$ Non-participating countries are Sweden, Ireland, and the United Kingdom.
} 
dissonance, avoiding conflict, and consequently diminishing the transformative potential of heritage (Harrison 2013; see also Turunen in this volume).

The EHL carries some characteristics of an AHD: the awarded sites are embedded in the national and/or local narratives of the EU-member states, and various heritage experts hold key positions in the process of awarding and managing the sites. However, instead of showing up as self-evidently European heritage, the EHL mixes local, national, and European scales in an endeavour to reconcile their dissonance and make the heritage suitable for constructing European identity narratives. Therefore, instead of a taken-for-granted European heritage, the EHL can be depicted as an authorization process, AHD in the making (cf. Smith 2006, 100; Kaasik-Krogerus 2019). The EHL sites are situated in the EU member states, whereas the system of meanings of what is European heritage is formed in interactions between European, national, and sometimes also local scales. Mobility between these intertwined scales as a combination of Europeanization (of the national and local) and domestication (of the European) forms the very essence of the EU.

Europeanization is defined as an international socialization (Schimmelfennig 2000) and used to depict the spheres of integration where formal and informal rules, procedures, policies, and norms are constructed at the European scale and then diffused to domestic institutions (Radaelli 2000, 4; Sassatelli 2008, 225; see also Schimmelfennig 1998, 198-200; 2000, 109-112; see also Kaasik-Krogerus 2016, 43-44). The domestic institutions and actors then incorporate the "European" with national and/or local conditions, a process that has been called "domestication" (Alasuutari 2009, 67). This process does not occur without struggle and conflict, if not against Europeanization then over the contents of policies, informal rules, as well as representations and constructions of heritage. Hence, as entangled processes of mobility and stability related to different scales, Europeanization and domestication create and reinforce the dissonance of European heritage, while at the same time attempts to manage that dissonance are also embedded in those same processes.

In this chapter, I focus on what can be called a "politics of mobility and stability". I scrutinize how a politics of mobility and stability is conducted as part of the EHL with the aim to manage dissonance related to local, national, and European scales. By politics, I refer to the attempts and/or abilities of the EHL-related actors to have certain meanings 
legitimized at the expense of others (cf. Smith 2006, 81). This politics of mobility and stability plays a crucial role in the EHL as an AHD in the making and consequently also in constructing EU narratives of identity and belonging as the cultural-symbolic foundation for political purposes (cf. Karlsson 2010, 38; Kraenzle and Mayr 2017, 2; see also Sassatelli 2002, 436; Delanty 2005, 409-410).

As empirical data I use the exhibitions at one of the EHL sites: the Great Guild Hall (the site is discussed also in the Turunen chapter). The site is situated in Tallinn, Estonia, and was awarded with the EHL in 2014. Since the Estonian History Museum is located in this medieval building situated in the old town of Tallinn, it offers rich data for analyzing the dissonance of entangled mobility and stability on local, national, and European scales. Furthermore, Estonia was one of the Central and East European (CEE) countries that joined the EU during the Eastern enlargement. ${ }^{2}$ As the EU's relation to the CEE countries, simultaneously depicts them as being and becoming European (for example Mälksoo 2006; Kaasik-Krogerus 2016; see also Jones and Subotic 2011, 544-546), this offers an additional nuance to the politics of mobility and stability conducted by the displays in the process of constructing knowledge at the site (see also Moser 2010, 22; De Cesari 2017). The study asks: How do the exhibitions conduct their politics of mobility and stability and with what effects? I also discuss the consequences of this politics for the EHL and the European identity narratives that the EC is attempting to construct.

The chapter starts with a closer look at the politics of mobility and stability in relation to the formation of an AHD, paying special attention to the dissonance of Europeanization and domestication. After introducing the empirical data, this chapter's analysis appears in a section scrutinizing two Great Guild Hall exhibitions: "Spirit of Survival. 11,000 years of Estonian History" and "Medieval pleasures. Festivals of the Great Guild in the fifteenth and sixteenth centuries".

\section{Politics of Mobility and Stability in Forming AHD}

Mobility is defined as movement ascribed with meaning: quality of being mobile, that is, an ability to move or being moved freely or in forced ways, whereas stability stands for the quality of not being likely to move

\footnotetext{
${ }^{2}$ Estonia joined the EU in 2004 together with nine other countries, and the so called Eastern enlargement continued in 2007 when Bulgaria and Romania joined the EU.
} 
or change but remaining stable (Oxford Living Dictionaries; Cambridge Dictionary). Both terms are also widely used in academic analysis. While Tim Cresswell (2001) writes that mobility refers to movement saturated with meanings that make that movement significant and bring along power dimensions, I would say the same about stability: it, too, brings along power dimensions and is saturated with meaning.

The essential nature of mobility in contemporary societies is captured in scholarly references to the "mobile turn" (Urry 2007, 6) or the "new mobilities paradigm" (Sheller and Urry 2006). Academic discussions debate the current condition of constant mobility within the framework of modernity (for example Bauman 2000; Sheller and Urry 2006; Urry 2007). Scholars tend to agree that, within the progress-oriented framework of modernity, mobility is widely seen as a social good, whereas stability (immobility) ${ }^{3}$ acquires a connotation of defeat, of failure, and of being left behind (for example Morley 2000, 202; see also Bauman $1998,2)$. That division between mobility and stability is analytical, however, since apart from advancing mobility, modernity is also invested in stability in the ways that it orders and classifies matters in order to tackle chaos, minimize risks, and withstand uncertainty (Harrison 2013, 227). Mobility and stability are therefore largely intertwined in modernity, and no strict boundaries between them can be drawn.

At the EU level, the four freedoms-free movement of people, goods, services, and capital_offer a good example of such a politics of mobility and stability. The EU promotes mobility for example in its programmes on culture and citizenship that stimulate transnational cooperation and exchange (Mäkinen 2014, 133). Furthermore, the policies and programmes of "everyday" mobility related to travel for work, education, tourism, and so on aim to bring Europeans closer in terms of common experiences (Delanty 2005, 410, 415; Karlsson 2010, 38). Nevertheless, during the EU's Eastern Enlargement in the beginning of the 2000s, it was debated whether or not the EU should temporarily restrict the mobility of the soon-to-be EU citizens on the labour market of the "old" EU countries. The transition periods some EU member states put in place for the new EU citizens are good examples of a politics that endeavours to manage the entangled notions of mobility and stability.

\footnotetext{
${ }^{3}$ As the term "immobility" refers to an absence of mobility and thus clearly contributes to valorizing mobility, I use "stability" in this chapter, since that word does not have such a negative connotation.
} 
A similar example can be found in the current fences built on the borders of some EU countries to restrict the mobility of people who seek refuge in the EU. These policies are conducted at the same time as these member states appreciate and benefit from the mobility options offered inter alia by the above-mentioned programmes of culture and citizenship. In the current volume, the chapters by Proglio and Trakilović provide solid analyses of this controversy.

In the context of heritage as a modern phenomenon, mobility and stability are also profoundly entangled. In temporal terms, an overall idea of AHD is to create stability by conserving and safeguarding sites, objects, and artefacts and by preserving intangible phenomena. By making the sites and phenomena durable, heritagization is supposed to protect and safeguard them from temporal decomposition. However, as critical heritage studies shows, even material or "fixed" heritage is continuously being constructed over time. This mobility in time can be grasped using Sharon Macdonald's term "past presencing", that is, selectively remembering and using pasts in the present $(2013,15-17$; see also Lähdesmäki in this volume). When what is and what is not worth preserving is being decided, the past is accordingly divided into valuable and valueless sections. Although heritage is a contemporary phenomenon, the key objective of the selective fostering of the past is to influence future developments (Harrison 2013).

In spatial terms, intertwining heritage with a physical location aims to place it and therefore stabilize it in space (for example McDowell 2008). Especially in (nation) states this fosters an understanding of them as self-sufficient and autonomous "containers" with a clear "inside" and "outside" (Beck 2000; about Europe, also see De Cesari 2017, 26). Thus, AHD often functions to make and maintain a distinction between the people who are accepted and those who are excluded. Seen from an alternative, heterotopic perspective, states are revealed to be not actually self-sufficient, instead being formed in interrelations with other, similar actors. Instead of self-sufficiency, what characterizes the modern state is its ongoing mobility of meanings and social relations (see Massey 1991, 2005, 118; Lehtonen 2004, 2013, 15-17). Consequently, this heterotopic perspective widens the spatial scale of heritage as well as the variety of actors involved. On the EHL application form (2017), for example, applicants are asked to describe how they "foster the mobility of European culture professionals, artists and collections, stimulate intercultural dialogue and encourage linkage between heritage and contemporary creation", emphasizing the importance of diverse social relations. 


\section{Dissonance of Europeanization and Domestication}

In this chapter I approach mobility and stability between local, national, and European scales as an interplay of Europeanization and domestication. This interplay both contributes to heritage dissonance and seeks to handle it through its politics of mobility and stability. In the context of Europeanization, norms, procedures, policies, and rules are first defined and consolidated at the European level, and then delivered to the national scale to incorporate them into domestic institutions and policies (Radaelli 2000, 4; Sassatelli 2008, 225; see also Schimmelfennig 1998, 198-200; 2000, 109-112; see also Kaasik-Krogerus 2016, 43-44). Discourses and practices related to EU policy are adapted to the domestic context, thus interpreting what is "European", and as a result national and local politics in different countries can largely differ from "original" European policy. The Eastern Enlargement presents a good example of domestication, as the states' national interpretations of EU policies also contribute to what is understood as "European" at the EU level. Yet, domestication is not an entirely domestic (national and local) process: since the same process takes place in different countries simultaneously, the domestic agenda in policy spheres tends to get synchronized with analogous political alignments in other countries (Alasuutari et al. 2013).

Different but interrelated processes of cultural Europeanization and the Eastern enlargement are fruitful cases to explore the interplay between Europeanization and domestication from the perspective of heritage. These interrelated processes started in the 1990s after the collapse of the Soviet Union. Cultural Europeanization is defined as a process that aims to strengthen a "sense of shared European identity amongst citizens of the various member states" (Kraenzle and Mayr 2017, 2). Although the very existence of any such single European identity narrative is questioned in this volume, endeavours to authorize European cultural heritage and use it to constructing common narratives deserve attention. While several authors write that cultural Europeanization followed the waves of economic and political integration (Karlsson 2010, 39; see also EU 2014, 4; Lähdesmäki 2019), the EU accession process-a key part of Europeanization-covered all three: political, economic, and cultural integration. Although both cultural Europeanization and the EU enlargement contribute to authorizing European heritage, they do this in opposite ways.

During the Eastern enlargement, the "Europeanization" of the political and economic spheres of the candidate countries (their "becoming 
European") was accompanied by a rhetoric according to which these countries culturally and historically formed an integral part of Europe ("being European"). References to a common past were used by both the EU and the candidate countries to legitimize EU membership as simultaneously a suitable scenario for the future and a "return to Europe" (Feldman 2001, 9) to which the countries had supposedly truly belonged to since at least the Middle Ages (see also KaasikKrogerus 2016). While this politics aimed to paint the Communist past as a rupture in a centuries-long continuity of belonging to Europe, it also strengthened the idea of a common European heritage and of CEE countries as part of that (see also Lähdesmäki et al. 2019). Since the assumption of such a centuries-long continuity that is embedded in European identity narratives is often legitimized with reference to a shared Christian background, on a European scale the argument strengthens the importance of Christian religions as a key part of this common heritage.

According to Klas-Göran Karlsson $(2010,38,44)$, in the context of cultural Europeanization, the European cache of cultural valuables temporarily becomes a site of negotiation between actors from different scales. During the accession process, common European heritage was used as an argument to legitimize the membership of the CEE countries, yet the EU also needs to authorize this common heritage without provoking the reactions of national-scale institutions (cf. Sassatelli 2002, 440; see also Kuus 2017, 3). As scholars write, this dissonance between the European and national scales is especially apparent after the latest accessions, when Central and East European countries have aspired to broaden "the store of collective memories" (Checkel and Katzenstein 2009, 3; see also Mälksoo 2009, 656; see also Jones and Subotic 2011, 554).

The EU's EHL action is a good example of this dissonance, as it also illuminates how actors who are related to different scales attempt to manage this dissonance by conducting a politics of mobility and stability. The sites apply for the label, whereas the decisions about "locating" European heritage at the sites are made by the EC. The chosen sites are introduced through videos that all follow a similar format and are available at the web page of the EC (see also Kaasik-Krogerus 2019). However, since the sites maintain their own daily practices "at home", they also choose how to Europeanize. Their chosen imaginaries of Europe impact the selection of their exhibitions, the viewpoints, and the angles taken when introducing historical events and persons, as well as 
the substance and format of the guided tours organized on the sites. This process clarifies why the "normalcy" and "taken for grantedness" characteristic of national AHD are not directly conveyable to the EHL.

\section{The Great Guild Hall as Empirical Data}

Framed on the EHL website as "one of the most distinguished societal buildings" in Tallinn, the Great Guild Hall was built in 1410, and is an example of Hanseatic architecture from the Middle Ages. In the EHL Panel Report, medieval Hanseatic history and the idea of continuity created on the basis of that is used to argue the European significance of the site. Since 1952, Estonian History Museum has operated in the hall, which was completely renovated in 2010-2011. The Great Guild that gives the Hall its name is characterized as a social, religious, and professional association intended for Tallinn's most important merchants of German origin during the Middle Ages, while important representatives of some other professions were also accepted. Remarkably, Estonians had no right to belong to the guild.

My analysis here focuses on the two exhibitions on the first floor of the Great Guild Hall. On the museum webpage and flyer, these are introduced as the core displays: the permanent "Spirit of Survival" exhibition which focuses on Estonian history as the "story of Estonians" over the past 11,000 years and is located in the great hall, and a temporary exhibition called "Medieval Pleasures", ${ }^{4}$ which was located in the small guildhall and dealt with the Great Guild Hall festivals in the fifteenth and sixteenth centuries. The other floors and their displays are out of the scope of this chapter. ${ }^{5}$

Since the "Spirit of Survival" has been up since 2011, it was not designed as an EHL exhibition. According to the museum flyer, the exhibition tells colorful stories of Estonian history and helps to understand the extraordinariness of the people who have lived "here". To tell these stories, the exhibits use text plates in Estonian and English as well as humorous interactive multiple-choice questions. Since texts

\footnotetext{
${ }^{4}$ The temporary exhibition was open from 25 May 2016 to 4 June 2017.

${ }^{5}$ They concern the history of the Great Guild Hall itself ("Power of the Elite") plus rooms focused on certain topics, like the Armory ("Wars through Estonia's History"), the "Experimentarium" education center ("Spirit of the Thing") as well as the Coin Room ("Striking it Rich?! Money in Estonia through the ages").
} 
dominate the displays, my analysis also focuses on those. The texts were made attractive for visitors by combining facts and figures with funny sayings and small jokes. Apart from those, my data consists of two videos displayed in the exhibition: "Spirit of Survival" and "Is Estonia a Nordic country?" Since the permanent exhibition is more extensive than "Medieval Pleasures", it also gets more attention in the empirical analysis.

The "Medieval Pleasures" focuses on the local scale and deals with the medieval festivals held at the Great Guild, which functioned as the main fora for communication between the guild members and strengthened their sense of community. As the title indicates, the exhibition does not claim to give a comprehensive overview of medieval times, but focuses on a single aspect of medieval life-partying and having fun. This choice makes the tone and the themes of this exhibition different from the familiar take on the Middle Ages as a dark era. Though based on facts, the story is told in a fictional and a joyful manner, mostly through the key figure of Urban Dene. Master of the Mint, Dene was a member of the Great Guild and probably the richest man in Tallinn at the time. He is introduced in the exhibit as a first-person narrator: "Around 1530, I arrived in Tallinn from Jülich in Germany. After six years I became a citizen and took a wife". Since the exhibition does not elaborate gender relations any further, they remain largely suspended.

\section{The Politics of Mobility and Stability IN THE EXHIBITIONS}

The empirical data was gathered through observation during my visits to the Great Guild Hall in October 2016 and September 2017. Apart from explicitly/concretely emphasized representations of mobility and stability, both also appear implicitly/abstractly in the exhibitions (cf. Palonen 2014; see also Lähdesmäki et al. 2019). Since the explicit and implicit layers are intertwined, I make no further distinction between them in the analysis.

By focusing on the representations in the displays, I analyze the Great Guild Hall as an actor that attempts to influence people by constructing knowledge through its exhibitions (see also Moser 2010, 22; De Cesari 2017). In this volume, Milica Trakilović analyses airports as sites where heritage and belonging are negotiated, and I apply similar approach to this museum. In the spirit of Sharon Macdonald (2013, 166), I analyze 
how the museum constructs identity stories in a three-dimensional space on the basis of cultural heritage. As part of an AHD in the making, the EHL site enables me to research the interplay and dissonance between local, national, and European scales, including its domestic intentions and consequences on European scale. I scrutinize how the displays of the Great Guild Hall construct mobility and stability in time and space to find out how the exhibitions' politics of mobility and stability handles dissonance. These politics work in two controversial ways: simultaneously legitimizing mobility and stability as natural and challenging them as problematic.

\section{Depoliticizing and Naturalizing Stability and Mobility}

The farm was headed by the man of the house; the oldest son usually inherited this position, and the farm was not divided. The younger siblings often stayed on the farm and worked as farmhands.

This quotation from the "Spirit of Survival" display is supposed to characterize the situation in Estonia until World War II. It provides an illustrative example of naturalizing stability. The text portrays people as very static in their everyday: the man of the house occupied ${ }^{6}$ a leading position, and the younger siblings stayed on the farm. The hereditary system and the fact that the farm was not divided exemplify the stability of the societal structures, including the clear role and labour division between men and women in the countryside at the time. The display also tells visitors how the changes in the twentieth century "significantly changed the roles of men and women, both in society and in the family" so that "the expression 'man of the house' has lost its original meaning".

In addition to farms other spatial scales are also used to indicate location-based stability. Visitors are told that Estonia is situated "on the outskirts of Europe". The claim that Estonia "found its place on the world map" in the fifteenth century, when some of its parts were mentioned on a Scandinavian map, shows that others have also recognized its long history. While the first ancestors of the people living on this land came from Africa, the claim that some of them were molded "into Estonians by time" contributes to the idea of Estonia as a formative "container". In this process, the symbolic value of the Estonian language as "the heart

\footnotetext{
${ }^{6}$ Literal translation of the Estonian verb, seisis (headed) would be 'was standing'.
} 
of this land and the people living here" is emphasized especially. One exhibit states that, while people from many nations have lived in Estonia, those "who have learned Estonian and can communicate with the natives in their language have always been loved most of all". Language thus works as a stabilizing factor that offers foreigners access to the container.

The "Is Estonia a Nordic country?" video provides a good example of how materiality and natural phenomena like climate, flora, and soil are used to promote the idea of stability. Though the video claims that the "Estonian ski mecca Otepää" has been around since the Ice Age, it should be noted that neither was the place always called Otepää, nor was the ski mecca open to skiers in the Ice Age. The video's conclusions about the ski mecca are drawn on the basis of the hilly landscape formed at the time. Creating this age-old connection gives both the place as well as the ski slopes (a rather recent phenomenon) a firm and long-lasting basis. As the title of the video implies, it also legitimizes Estonia as a Nordic country, with all the supposed stability that entails (more about this in Kaasik-Krogerus 2017).

The "roots" metaphor also forms a strong basis for stability in the display: it "places" (even "plants") people and therefore makes a firm (almost organic) container of the country and its people. Among those who are "inside", this setting supposedly evokes pride (of maintaining stability no matter what) and safety (experience shows that roots will last), whereas from the ones "outside" respect and compassion is expected. Accordingly urging stability of people and the country is not related to the idea of them being left behind in terms of development.

By claiming that the "Estonian spirit's meant for survival", the permanent exhibition depicts a struggle between the community and their harsh circumstances as one where "[t]he Lord helps those who help themselves". Although the saying might seem religious, it actually takes an ironic stand towards God and religion, indicating that it is naive to hope that somebody else is going to solve your problems. This continuous "struggle for survival" is depicted as taking place amidst a hard climate, rocky soil, not to mention plagues and famines. These conditions are shown not to intimidate Estonians, however, as the exhibition states that they have been loyal to their home country throughout history despite these hardships. Thus, they can be depicted as "winners".

On the individual level, temporal context is used in the "Spirit of Survival" to frame the phases of human life from birth to death. In this path, "natural" rituals like weddings are claimed to contribute to 
stability. Rituals also structure the temporary exhibition "Medieval Pleasures", which is built around annual festivities, the biggest and most important of which being two very different events: the Shrovetide (Carnival) and the Christmas Festival. The exhibits introduce rituals related to the structure and content of the events. The display presents Carnival entertainments like wearing masks or costumes representing animals, devils, or the opposite sex. Additionally, attention is paid to the games that were played and the food and drinks that were consumed during the festivities. While the exhibits note that masked people were also seen as a potential threat to the public order during the Carnival, the measures, such as fines, for handling potential violations, are presented as well. Implicitly, however, the exhibition communicated a more abstract interpretation of the Carnival as an event that challenged societal stability and the prevailing order. In the spirit of Bakhtin (1984), the masks and Carnival activities can be interpreted as a performance of temporal liberation empowering disadvantaged people by turning the world upside down for a short time period and building a frame within which the powerful could be mocked and ridiculed.

There were also points where mobility was naturalized in the exhibitions. In the permanent exhibition, mobility inside the country through phenomena like urbanization is legitimized by showing it as a "normal" societal evolution. Certain forms of mobility from other places to Estonia, like borrowing words from other languages, are justified by praising foreign influence as being beneficial from the local perspective.

As the permanent exhibition tells the visitors, factories were built while the Industrial Revolution "reached Estonia". Concerning religion, the display claims that the Orthodox Church arrived in Estonia in the eleventh century, whereas Lutheran ideas "spread and made the local population receptive to the Protestant Reformation in the sixteenth century". "Medieval Pleasures", meanwhile, emphasizes the German background of the guild, as the guild members, starting from Urban Dene, are from Germany. These examples show how mobility is naturalized by detaching the processes from human agency, blurring it and releasing it from responsibility. Consequently social and political phenomena "reach" and "spread" similarly to weather conditions, and therefore smoothly become part of "normal" reality.

Examples of such "naturalized" mobility also show up from Tallinn and Estonia to the world. Since the Great Guild Hall was a brotherhood of merchants, "Medieval Pleasures" emphasizes the importance 
of trade. "Spirit of Survival" also presents Estonia's exports as an ordinary form of mobility since ancient times. As the permanent exhibition tells the visitors, iron exports were replaced by grain in the Middle Ages, and in the nineteenth century by linen, amber, foodstuffs, and alcohol. Nowadays, the focus is largely on services: "Estonians have given the world the Internet telephone service Skype and several different innovative e-services".

That idea of "giving something to the world" is widened to the world-famous people who have been born and/or lived in Estonia. The permanent exhibition states that: "Tiny Estonia has had an influence $[\ldots]$ that is much greater than its territory", since various internationally known figures "have emerged from Estonia's multicultural and ethnically diverse history". Unlike the vague way agency appears in accounts of mobility to Estonia, here the agency of both Estonia as well as several famous individuals is emphasized. This creates a paradox of simultaneous superiority and inferiority. The famous people are implicitly represented as superior to the domestic community and Estonia as superior to "the world", to whom it has "given" key e-services. On the other hand, the need to leave your homeland to become known and famous elsewhere refers to a certain kind of intellectual exile (cf. Camurri 2014); the display does not elaborate on whether these exiles were voluntary or forced. The idea that in order to become world famous you have to leave your country itself, however, is constituted by and maintains a setting of periphery (Estonia) and centre ("the world"). As the exhibition states, famous people emerged "despite unfavorable conditions such as Estonia's small population and location on the periphery of Europe". By becoming "the Eastern border of the EU" in 2004, Estonia itself also "moved" symbolically. The idea of "becoming European" is therefore embedded in the exhibits' representation of natural mobility.

In sum, while in "Medieval Pleasures" rituals create stability, in "Spirit of Survival" different spheres of life are stabilized in various ways. As a result, Estonia stands for a self-sufficient, largely natural, and material container of a tightly interlinked soil/country and people, without much interaction with the rest of the world (including Europe). This bears similarities to the idea of "from-here-ness" or "people from here" as a survival strategy for making a distinction between oppressors and oppressed nation (cf. Pershai 2008, 86-87). The permanent exhibition naturalizes mobility by combining stories about the societal processes that reach Estonia and contribute to its development with ones about Estonian 
agency impacting "the world". Although the connections between "in-" and "outside" are valorized, their interaction remains rather vague, since the counterparts of Estonia remain unknown or are mapped in an abstract way (for instance by talking about "the world"). Though the focus is first and foremost on the city (Tallinn) or country (Estonia), it is also widened to include the European scale, since Estonia is implicitly or explicitly situated with regards to Europe. Portraying stability as a natural order of things means that no changes are foreseen to the idea of "being European", whereas the mobility between Estonia and Europe is related to "becoming European" in a process of Europeanization and domestication.

\section{Problematizing and Politicizing Stability and Mobility}

"Spirit of Survival" problematizes mobility and stability in cases when Estonia and "the world" are interrelated but do not interact. As a result, Estonia is seen to be affected by the other actors through ambiguous processes. Like the exhibition crystallizes, Russians and Germans "have oppressed Estonians the most but have also enriched the history and culture". Estonia here becomes an arena for oppressive mobility and "target of pillaging and military campaigns" like crusades, invasions, occupations, wars, and conquests. As the permanent exhibition explains, over ten foreign powers have ruled Estonia in the past 800 years, "dislocating" the country by incorporating it into different states (the Russian Empire) or dividing its territory between powers (the king of Denmark, a German military order, and the bishops of Western and Eastern Estonia). Little by little, this oppressive mobility develops into to an oppressive stability, like being incorporated into the Soviet Union for fifty years.

Soldiers and armies, but also powerful, coercive foreign immigrants like the German-speaking nobility, are represented as agents who entered the country, shook the landscape and the borders, shaped the land, and diminished agency of the local individuals. "Spirit of Survival" tells visitors that the German-speaking nobility who ruled the country for centuries "regarded Estonians as nothing but peasants and servants" and described them as "pitiful and pathetic, barbaric, dirty, lazy, and promiscuous". Accordingly, documents from the sale of an Estonian peasant are showcased as artefacts that prove the country's extreme state of both forced stability and mobility (Fig. 6.1). These handwritten pieces of paper 
with red stamps concreticize the meaning of oppression on a micro level and offer a personalized perspective (see also Macdonald 2013, 235).

While various authors in this volume discuss current immigration issues (see the chapters of Trakilović and Proglio), the Estonian case enables me to elaborate on the relations between the exhibitions' narratives about the past and the current attitudes towards immigration. During the country's EU accession process, some fear of immigration from the EU to Estonia was expressed (Kaasik-Krogerus 2016, 184), but most attention was targeted towards preventing immigration from Russia by keeping EU's eastern border strong. Currently, 62\% of Estonian respondents (compared to $38 \%$ of the EU average) mention immigration as one of the main concerns at the European level (Standard Eurobarometer 87, 2017). According to the government of Estonia, 226 applications for international protection were received in 2015, and protection was granted to 78 people. By the end of 2017, 171 refugees who arrived in other EU countries had been relocated to Estonia. Hence, the Estonians' concern seems to be mostly fueled by the mediated transnational "refugee crisis" discourse rather than rooted in the current social reality in the country. Simultaneously, the situation is interpreted in the context of the historical migrations, like the one that took place during the Soviet period, that resulted in local people being put in a subordinate position.

The exhibition's examples of problematized mobility also depict the mobility of Estonian people who were forced to leave their home/country. As the permanent exhibition explains, during the Middle Ages people escaped serfdom by leaving the countryside to become free in towns. During mass deportations in 1940s, thirty thousand people were taken from their homes and sent to Siberia, tens of thousands escaped to the West, and many fled to the woods to continue fight against Soviets as guerillas. Consequently, World War II is depicted as having left Estonians "fearful and distrustful":

Both World War II and the occupations brought brutal repression against landowners and their property. Most of the farms were absorbed into collective farms (known as kolkhozes) - an act from which country people still have not fully recovered.

And yet the exhibits do not paint Estonia as a place without a future, since the permanent exhibition also depicts people's resistance as a mixture of victimhood and heroism (see also Bogumił et al. 2015, 80). 
Resistance means finding appropriate methods and tools to persist under oppressive conditions and undermine the regime. Humour is an important tool of resistance, and the exhibition notes that a "sarcastic sense of humour" is a crucial part of Estonians' self-perception, helping them deal with serious and painful issues as well as depicting themselves through a humorous prism. Broadly speaking, irony is seen to add strength to arguments (Pettersson et al. 2017, 633). Irony also helps to regain a sense of agency as an observer who reflects things. As the exhibition states, Estonians make fun of their neighbours and rulers, and show off their own superiority as being more clever.

The exhibitions also use humour in their displays. In "Spirit of Survival", this first and foremost occurs in carnivalesque forms of textual and visual self-irony. In a video in which famous historical figures alternate to "tell" the story of Estonia, apart from a few well known actors as a poet Lydia Koidula and a former president of Estonia Konstantin Päts, figure also fictional characters such as the Spirit of Survival and a giant amphibian from a local fairy tale, the Dragon of the North. ${ }^{7}$ In fact, the video installation gives a funny impression of all its characters, since animation is combined with historical footage. From the visitors' perspective these elements make the display fun and entertaining, even though the issues and events it deals with, like wars and oppression, are not funny at all. While on the one hand this humorous approach helps visitors to digest this difficult past, on the other hand the video also is a great example of how humour is used for political purposes against holders of power from oppressive regimes.

In "Medieval Pleasures", joyful humour is combined with playfulness as an example of escaping the worries of everyday. Visitors are encouraged through exclamations like "Let's play something!" and "Fun hasn't been lost!" The festivities are described in an exaggeratedly careless manner, emphasizing the importance of the joy of the moment, if necessary even at the expense of the future. The mask of the devil that can be tried on is an example of how visitors are urged to participate. Hence, while "Spirit of Survival" uses irony to problematize and make visible oppressive mobility and stability, "Medieval Pleasures" uses humour and joy to keep away everyday problems as well as the presupposed darkness of the Middle Ages. At the same time, the exhibition communicates a rather

\footnotetext{
${ }^{7}$ The Estonian name for the creature is Põhja konn.
} 
timeless message, telling visitors that no political regime is capable of preventing or banning humour.

In sum, while it was relatively easy to make a distinction between naturalized mobility and naturalized stability, problematic mobility and problematic stability are tightly intertwined in the exhibition, since problematic mobility (as evinced by wars, for instance) is "finalized" through oppressive stability in a form of occupation. In this process, the exhibits depict clear positions of agency. The permanent exhibition points to certain countries, particularly Russia and Germany, as responsible for centuries-long oppression, whereas larger entities like "Europe" are missing from this "dirty business". While the scholarly debate increasingly demands that not only single EU-member states, but also the union (as "Europe") should take responsibility for its dark history, for example with regards to colonization (for example Heinze 2012, 211; SchmidtGleim and Wiesner 2014, 12; see also Turunen and van Huis in this volume), in the permanent exhibition "Europe" implicitly forms a bright spot in the darkness as a potential positive story among many negative ones.

\section{Discussion And Conclusions}

The Great Guild Hall presents a great example of negotiating the boundaries of pluralization in the context of the EHL. Since the Great Guild Hall houses the Estonian History Museum, its permanent exhibition can be studied for its "past-presencing" of narratives of the nation and the country. The permanent exhibition introduces Estonia and its history as an integral part of Europe and museum experts see that this understanding does not need to be explicitly emphasized. ${ }^{8}$ This way, any dissonance between the national and European scale is managed by removing it from the authorization process.

However, this management is noted and criticized in the EHL documents. The EHL Panel report ${ }^{9}$ encourages the Great Guild Hall to use the recent history of Estonia to present "the narrative of Estonia and Estonian people within the context of European history and integration" (2013).

\footnotetext{
${ }^{8}$ Author's research interview with the experts of the Great Guild Hall, 7 September 2017.

${ }^{9}$ The panel reports include recommendations for the attribution of the EHL and provide explanations for its conclusions.
} 
Later, the Monitoring Report ${ }^{10}$ urges "a thorough rethinking [... on how to contextualize the mainly Estonian national history narrative in a wider European perspective" $(2016,15)$.

This interaction between the national and European scale illustrates the controversies and complexities related to identity construction well. On one hand, the claims of being an "integral part of Europe" counter the EHL documents' Othering claims that state the current narratives of the Great Guild Hall are not "European enough". Yet on the other hand, the same claims of being European enable a different kind Othering by making an implicit distinction between Europe and what is left outside. Therefore, any attempts to tackle exclusion simultaneously also evoke it towards others. This illuminates the dissonance between the intentions at the national scale and their consequences on the European one. In what follows, I will draw conclusions about this dissonance with regards to power relations, spatial scales, and future imaginaries of AHD in the making from the perspective of constructing European identity narratives.

First, to return to the EHL slogan, starting points of Europe ("here") can be located in the Great Guild Hall building and the city of Tallinn ("Medieval Pleasures") as well as in Estonia ("Spirit of Survival"). The depictions of country's difficult past are also used more widely in Estonian public discussions to justify a depoliticized longing for stability. What gets obscured, however, when this narrative of external oppression is extended from the past to today, is that although the arguments remain unchanged, their consequences alter, and empowering the powerless thus turns into excluding Others. This is due to a change in power relations, since the same tools and means have very different consequences depending on whether they are used by oppressed people or by a EU member state. The same politics might thus lead towards empowerment or exclusion, and it is scarcely perceptible where or when one turns into the other. Hence, instead of studying who does or does not exercise power, what deserves attention is the complexity of the process of (re)gaining power. In the case of Estonia, new narratives depicting it as a leading information society (for example Mäe 2017) appear right alongside ones that are dominated by its oppressive past. The war in

${ }^{10} 2016$ was the first year when the sites awarded in 2013 and 2014 were examined by the European Monitoring Panel. Sites are monitored to ensure that they continue to meet the criteria for which they were selected. 
Ukraine evoked fear throughout the Baltic countries, and despite being "officially European" through their membership in the EU and NATO, a dark future was (silently) imagined on the basis of the countries' past experience. Political debates at the European scale often reduce this puzzle either to a narrative of victims or one of the intolerance and ignorance of the "Eastern Block countries". Ironically, public discussion about the EU who is "hit" or "flooded" by the refugee crisis, repeats similar victim position on the European scale.

Second, in spatial terms, the heritage discourse of the Great Guild Hall is an example of multi-scalarity, covering everything from farms and small towns to Estonia and Europe. However, while Huot et al. (2014, 330) map out multi-scalarity on the basis of different, partly overlapping scales of communities (city, nation, region, etc.), in the current case the scales are also contradictory. The exhibitions are an example of simultaneously displaying common heritage and dissonant multiheritage (Macdonald 2013, 162). This holds true particularly when we compare the two exhibitions: the exclusion of Estonians from the Great Guild is not problematized in "Medieval Pleasures", for example, whereas "Spirit of Survival" talks about Estonians as one of the most unhappy people in Europe, "second-class citizens in their own land for a long time, starting from the thirteenth century". In the EHL's site video of the Great Guild Hall, the museum representative says that on the basis of the exhibition visitors could understand how Estonian identity is connected to European identity. This is especially clear in the permanent exhibition, which domesticates Europe by elaborating it in relation to Estonia. Here, Europe as a stable context is interlinked with the national scale (of the EU's member states), obscuring how the agency of "Europe/the EU" impacts a variety of scales, including the global one.

Third, since heritage is formed in the present with an aim to influence the future, the key question is what kind of future is imagined to and for whom. On the basis of the video "Is Estonia a Nordic country?", the "Europe starts here" slogan can be domesticated as a (supposedly permanent) end to oppression that was sealed by Estonia's joining the EU in 2004. In this setting, the EU stands for a survival that enables the country to move on. However, a context described in the permanent exhibition where "Happiness is being alive" does not facilitate bright imaginaries of the future. Since most of the stories from the past do not offer "happy endings", hope is instead communicated by a silence around the future. From an Estonian perspective, this silence shows an attempt to have a story (independence followed by the country's EU 


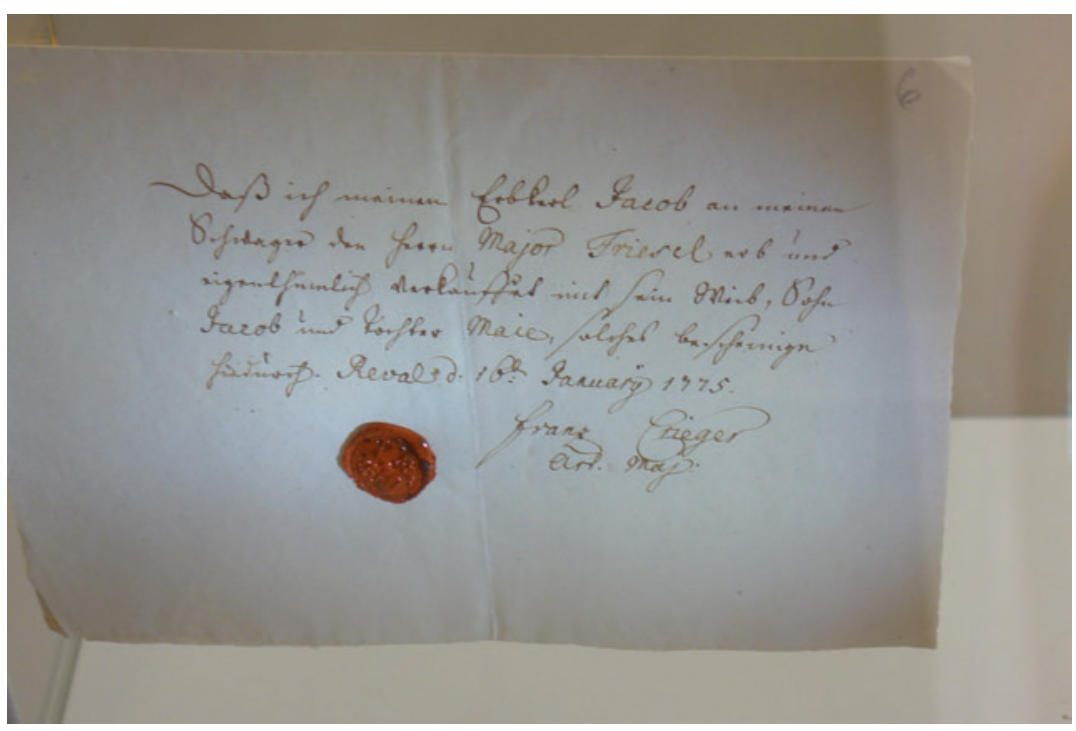

Fig. 6.1 This document of the sale of an Estonian peasant from the eighteenth century is an example of both oppressive stability and oppressive mobility from one owner to the next

accession) that could lead towards a "normal" future. A lack of explicitly plotted future imaginaries means that visitors are given some specs to conclude the story by themselves. Consequently, the exhibition posits the EU as more or less fixed to the year 2004, the "good old times" before the current crises of the union, as the latter are outside the scope of the permanent exhibition. The Hall's setting resembles fairy tales that end with a wedding (EU accession), not with a depiction of a married couple's daily life. In the background, though, the EU (and tacitly Europe) is a "good guy" in the story (vis-à-vis the Russian and German "bad guys" from history). This implicitly rejects any potential criticism against the EU.

Acknowledgements This work was supported by the European Research Council (ERC) under the EU's Horizon 2020 Research and Innovation Programme under Grant 636177 (EUROHERIT). The content of this chapter does not reflect the official opinion of the European Union. Responsibility for the information and views expressed in the chapter lies entirely with the author. 


\section{REFERENCES}

Alasuutari, P. 2009. The Domestication of Worldwide Policy Models. Ethnologia Europaea 39 (1): 66-71.

Alasuutari, P., E. Mikola, M. Rautalin, J. Syväterä, and L. Valkeasuo. 2013. Globaalien kehityslinjojen luominen ja kotoistaminen. In Liikkuva maailma, ed. M. Lehtonen, 7-29. Tampere: Vastapaino.

Bakhtin, M. 1984. Rabelais and His World, trans. H. Iswolsky. Bloomington: Indiana University Press.

Bauman, Z. 1998. Globalization: The Human Consequences. Cambridge: Polity Press.

Bauman, Z. 2000. Liquid Modernity. Cambridge: Polity Press.

Beck, U. 2000 [1997]. What Is Globalization? Cambridge: Polity Press.

Bogumił, Z., J. Wawrzyniak, T. Buchen, C. Ganzer, and M. Senina. 2015. The Enemy on Display: The Second World War in Eastern European Museums. New York and Oxford: Berghahn Books.

Cambridge Dictionary. https://dictionary.cambridge.org. Accessed 16 August 2017.

Camurri, R. 2014. The Exile Experience Reconsidered: A Comparative Perspective in European Cultural Migration During the Interwar Period. Transatlantica 1. http://journals.openedition.org/transatlantica/6920. Accessed 2 February 2018.

Checkel, J.T., and P.J. Katzenstein. 2009. The Politicization of European Identities. In European Identity, ed. J.T. Checkel and P.J. Katzenstein, 1-28. Cambridge: Cambridge University Press.

Cresswell, T. 2001. The Production of Mobilities. New Formations 43: 11-25.

De Cesari, C. 2017. Museums of Europe: Tangles of Memory, Borders, and Race. Museum Anthropology 40: 18-35.

Delanty, G. 2005. The Idea of a Cosmopolitan Europe: On the Cultural Significance of Europeanization. International Review of Sociology 15 (3): $405-421$.

EC (The European Commission). 2013. European Heritage Label. 2013 Panel Report. Brussels: European Commission.

EC (The European Commission). 2016. European Heritage Label. Monitoring Report. Brussels: European Commission.

EC (The European Commission). 2017. European Heritage Label. Application Form. Brussels: European Commission.

EC (The European Commission). 2017. Standard Eurobarometer 87. http:// ec.europa.eu/commfrontoffice/publicopinion/index.cfm/Survey/getSurveyDetail/instruments/STANDARD/surveyKy/2142. Accessed 3 September 2017. 
EP\&C (The European Parliament and the Council of the European Union). 2014. Proposal for a Decision of the European Parliament and of the Council Amending Decision. No. 445/2014/EU Establishing a Union Action for the European Capitals of Culture for the Years 2020 to 2033. Official Journal of the European Union, L 132.

Fairclough, N. 1995. Media Discourse. London: Edward Arnold.

Feldman, M. 2001. European Integration and the Discourse of National Identity in Estonia. National Identities 3: 5-21.

Harrison, R. 2013. Heritage: Critical Approaches. London: Routledge.

Heinze, E. 2012. The Reality and Hyper-Reality of Human Rights: Public Consciousness and the Mass Media. In Examining Critical Perspectives on Human Rights, ed. R. Dickinson, E. Katselli, C. Murray, and O.W. Pedersen, 193-216. Cambridge: Cambridge University Press.

Huot, S., B. Dodson, and D.L. Rudman. 2014. Negotiating Belonging Following Migration: Exploring the Relationship Between Place and Identity in Francophone Minority Communities. The Canadian Geographer/Le Géographe canadien 58 (3): 329-340.

Jones, S., and J. Subotić. 2011. Fantasies of Power: Performing Europeanization on the European Periphery. European Journal of Cultural Studies 14 (5): 542-557.

Kaasik-Krogerus, S. 2016. Normative Stories of the Formative Moment: Construction of Estonian National Identity in Postimees During the EU Accession Process. Helsinki: Unigrafia.

Kaasik-Krogerus, S. 2017. Kuvitellut Pohjoismaat Viron presidenttien puheissa. Idüntutkimus 24 (2): 18-32.

Kaasik-Krogerus S. 2019. Identity Politics of the Promotional Videos of the European Heritage Label. Contemporary Politics. https://doi.org/10.1080/ 13569775.2019 .1611207$.

Karlsson, K. 2010. The Uses of History and the Third Wave of Europeanization. In A European Memory? Contested Histories and Politics of Remembrance, ed. B. Strath and M. Pakier, 38-52. New York and Oxford: Berghahn Books.

Kisić, V. 2017. Governing Heritage Dissonance: Promises and Realities of Selected Cultural Policies. Amsterdam: European Cultural Foundation.

Kraenzle, C., and M. Mayr. 2017. Introduction: The Usable Pasts and Futures of Transnational European Memories. In The Changing Place of Europe in Global Memory Cultures: Usable Pasts and Futures, ed. C. Kraenzle and M. Mayr, 1-21. Basingstoke: Palgrave Macmillan.

Kuus, M. 2017. Locating Europe's power, or the Difference Between Passports and Passporting. In Interventions in Europe's Political Futures (with F. McConnell, A. Jeffrey, A. Smith, N. Vaughan-Williams, and H. Crawley). Political Geography 60: 261-271. 
Lähdesmäki, T. 2019. Taide, paikka ja kuulumisen politiikka EU:n Eurooppaprojektissa. In Kunlumisen reittejä taiteessa, ed. K. Hiltunen and N. Sääskilahti. Turku: Eetos.

Lähdesmäki, T., S. Kaasik-Krogerus, and K. Mäkinen. 2019. Genealogy of the Concept of Heritage in the European Commission's Policy Discourse. Contributions to the History of Concepts 14 (1): 115-139.

Lehtonen, M. 2004. Johdanto: Säiliöstä suhdekimppuun. In Suomi toisin sanoen, ed. M. Lehtonen, O. Löytty, and P. Ruuska, 9-28. Tampere: Vastapaino.

Lehtonen, M. 2013. Miten tutkia liikkuvaa maailmaa? In Liikkuva maailma, ed. M. Lehtonen, 7-29. Tampere: Vastapaino.

Macdonald, S. 2013. Memorylands: Heritage and Identity in Europe Today. London: Routledge.

Mäe, R. 2017. The Story of e-Estonia: A Discourse-Theoretical Approach. Baltic Worlds 1-2: 32-44.

Mäkinen, K. 2014. Constructing Europe as an Area via EU Documents on Citizenship and Culture. In The Meanings of Europe: Changes and Exchanges of a Contested Concept, ed. C. Wiesner and M. Schmidt-Gleim, 130-143. London: Routledge.

Mälksoo, M. 2006. From Existential Politics Towards Normal Politics? The Baltic States in the Enlarged Europe. Security Dialogue 37: 275-297.

Mälksoo, M. 2009. The Memory Politics of Becoming European: The East European Subalterns and the Collective Memory of Europe. European Journal of International Relations 15 (4): 653-680.

Massey, D. 1991. A Global Sense of Place. Marxism Today, June: 24-29.

Massey, D. 2005. For Space. London: Sage.

McDowell, S. 2008. Heritage, Memory and Identity. In The Ashgate Research Companion to Heritage and Identity, ed. B. Graham and P. Howard, 37-53. Burlington (VT): Ashgate.

Morley, D. 2000. Home Territories: Media, Mobility and Identity. London: Routledge.

Moser, S. 2010. The Devil Is in the Detail: Museum Displays and the Creation of Knowledge. Museum Anthropology 33 (1): 22-32.

Oxford Living Dictionaries. https://en.oxforddictionaries.com. Accessed 16 August 2017.

Palonen, E. 2014. Assigning Meaning to (EU-)Europe Through Cultural Policy. In The Meanings of Europe: Changes and Exchanges of a Contested Concept, ed. C. Wiesner and M. Schmidt-Gleim, 144-159. London: Routledge.

Pershai, A. 2008. Localness and Mobility in Belarusian Nationalism: The Tactic of Tuteishaść. Nationalities Papers 36 (1): 85-103.

Pettersson, K., K. Liebkind, and I. Sakki. 2017. You Who Are an ImmigrantWhy Are You in the Sweden Democrats? Discourse \& Society 26 (6): 624-64l. 
Radaelli, C.M. 2000. Whither Europeanisation? Concept Stretching and Substantive Change. European Integration Online Papers (EIoP) 4 (8).

Raik, K. 2003. Democratic Politics or the Implementation of Inevitabilities? Estonia's Democracy and Integration into the European Union. Tartu: Tartu University Press.

Sassatelli, M. 2002. Imagined Europe: The Shaping of a European Cultural Identity Through EU Cultural Policy. European Journal of Social Theory 5 (4): 435-451.

Sassatelli, M. 2008. European Cultural Space in the European Cities of Culture. European Societies 10 (2): 225-245.

Schimmelfennig, F. 1998. NATO Enlargement: A Constructivist Explanation. Security Studies 8: 198-234.

Schimmelfennig, F. 2000. International Socialization in the New Europe: Rational Action in an Institutional Environment. European Journal of International Relations 5: 109-139.

Schmidt-Gleim, M., and C. Wiesner. 2014. The Meanings of Europe: Introduction. In The Meanings of Europe: Changes and Exchanges of a Contested Concept, ed. C. Wiesner and M. Schmidt-Gleim, 1-15. London: Routledge.

Sheller, M., and J. Urry. 2006. The New Mobilities Paradigm. Environment and Planning A 38: 207-226.

Smith, L. 2006. Uses of Heritage. London: Routledge.

Urry, J. 2007. Mobilities. Cambridge: Polity Press.

Waterton, E., and L. Smith. 2009. There Is No Such Thing as Heritage. In Taking Archaeology Out of Heritage, ed. E. Waterton and L. Smith, 10-27. Cambridge: Cambridge Scholars Publishing.

Open Access This chapter is licensed under the terms of the Creative Commons Attribution 4.0 International License (http://creativecommons.org/licenses/ by $/ 4.0 /$ ), which permits use, sharing, adaptation, distribution and reproduction in any medium or format, as long as you give appropriate credit to the original author(s) and the source, provide a link to the Creative Commons license and indicate if changes were made.

The images or other third party material in this chapter are included in the chapter's Creative Commons license, unless indicated otherwise in a credit line to the material. If material is not included in the chapter's Creative Commons license and your intended use is not permitted by statutory regulation or exceeds the permitted use, you will need to obtain permission directly from the copyright holder.

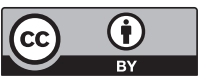

